This Journal is available in Telkom University online Journals

Jurnal Manajemen Indonesia

\title{
Etika Kerja Islam, Komitmen Organisasi, Sikap pada Perubahan Organisasi terhadap Kinerja
}

Prima Utama Wardoyo Putro, S.E., M.M

Prodi S1 Manajemen, Fakultas Ekonomi dan Bisnis, Universitas PGRI Madiun, Indonesia

\begin{abstract}
The subject of this study is to examine the impact of Islamic work ethics, organizational commitment, and attitude toward organizational change to work performance, where attitude toward organizational change as an intervening. Organizational commitment consists of affective commitment, normative commitment, and continuance commitment. The samples of this research are theacers of state Islamic school in Sragen Regency. The instrument analysis to test the model is AMOS. The result showed that Islamic work ethics has no positif significant effect to work performance and attitude toward organizational change. Either organizational commitment has no positif significant effect to performance. Organizational commitment has positif significant effect to attitude toward organizational change and attitude toward organizational change has positif significant effect to performance. The variable of attitude toward organizational change has no mediation effect between Islamic work ethics to work performance, and has no mediation effect between organizational commitments toward work performance.
\end{abstract}

Keyword-Work Performance; Islamic Work Ethics; Attitude Toward Organizational Change; Organizational Change; Commitment

\begin{abstract}
Abstrak
Dalam penelitian ini, diuji pengaruh antara etika kerja Islam, komitmen organisasi, dan sikap pada perubahan organisasi terhadap kinerja karyawan. Dalam penelitian ini, komitmen organisasi didasari pada tiga aspek: affective commitment, normative commitment, dan continuance commitment. Sampel yang digunakan dalam penelitian ini adalah guru yang dikhususkan pada sekolah Islam (madrasah) di Kabupaten Sragen. Penelitian ini menggunakan AMOS sebagai alat analisisnya. Berdasarkan hasil penelitian diperoleh bahwa etika kerja Islam, komitmen organisasi, dan sikap pada perubahan organisasi tidak memberikan pengaruh signifikan terhadap kinerja guru. Sementara itu komitmen organisasi berpengaruh signifikan pada sikap terhadap perubahan organisasi. Sikap terhadap perubahan organisasi juga berpengaruh pada kinerja guru. Variabel sikap terhadap perubahan organisasi tidak memediasi hubungan antara variabel etika kerja Islam pada kinerja dan tidak memediasi antara komitmen organisasi pada kinerja.
\end{abstract}

Kata kunci-Kinerja; Etika Kerja Islam; Sikap pada Perubahan Organisasi; Perubahan Organisasi; Komitmen

\section{INTRODUCTION}

Kinerja diartikan sebagai sebuah pencapaian atau hasil dari tindakan yang dilakukan melalui keahlian yang dimiliki oleh seorang karyawan yang bertindak pada situasi tertentu (Prasetya, 2011). Kinerja karyawan memiliki pengaruh yang penting dalam sebuah perusahaan atau organisasi, karena kinerja karyawan memiliki kaitan dengan pencapaian tujuan organisasi yang telah ditetapkan oleh organisasi. Semakin baik kinerja karyawan di sebuah organisasi, maka peluang tercapainya tujuan atau goal organisasi semakin besar.

Faktor yang memiliki pengaruh terhadap kinerja salah satunya adalah attitude toward organizational change atau sikap karyawan dalam menghadapi perubahan organisasi. Susanty \& Rizqi (2013) dalam penelitiannya menemukan bukti bahwa sikap seorang karyawan dalam memandang perubahan organisasi memberikan

\section{Article info}

Received (31 ${ }^{\text {st }}$ March, 2018)

Revised (16 ${ }^{\text {th }}$ April, 2018)

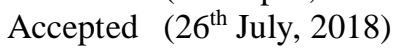

Corresponding_author: primautama28@gmail.com 
pengaruh positif signifikan terhadap kinerja karyawan. Karyawan yang memiliki sikap positif terhadap perubahan, maka dia akan mampu mencapai tujuan organisasi yang ditunjukkan melalui kinerja (Eby et al, 2000).

Perubahan merupakan salah satu faktor yang tidak akan mungkin bisa dihindari oleh sebuah organisasi. Sebagai bentuk fleksibilitasnya, organisasi harus mau dan berani menghadapi perubahan. Bentuk fleksibilitas dalam menghadapi perubahan tersebut merupakan salah satu cara menyesuaikan diri organisasi terhadap lingkungannya (Yousef, 2000).

Sebagian besar organisasi melakukan perubahan dikarenakan tuntutan dari lingkungannya. Proses yang harus dilalui sebuah organisasi untuk berubah unik dan rumit berdasarkan kondisi tertentu. Perbedaan situasi dalam proses perubahan ini bergantung dari faktor bisnis, lingkungan, budaya, ekonomi, sosial, teknologi, dan sikap karyawan (Abdul Rashid et al, 2004). Salah satu kunci sukses perubahan organisasi adalah sumber daya manusia yang dimilikinya (Januarti et al, 2006).

Sikap karyawan dalam menghadapi perubahan didalam organisasi merupakan sebuah emosional karyawan untuk memandang perubahan sebagai sesuatu yang positif atau negatif (Khatoon \& Farooq, 2015) Karenanya, jika sebuah perusahaan atau organisasi memiliki sumber daya manusia yang bisa memandang positif sebuah perubahan, maka bisa dipastikan proses perubahan organisasi tersebut akan berjalan lancar. Sebaliknya, jika sumber daya manusia organisasi resisten dalam menghadapi perubahan, maka proses untuk melakukan perubahan akan lama.

Ada tiga faktor yang perlu menjadi perhatian organisasi dalam melakukan perubahan menurut Listone dan Mitroff, yaitu: organisasi, teknologi, dan sudut pandang pribadi. Dalam hal tersebut, perspektif pribadi merupakan faktor yang sulit untuk ditangani. Oleh karenanya, penanganan sumber daya manusia dalam sebuah organisasi merupakan fokus yang sangat serius dan menjadi perhatian utama.

Sikap terhadap perubahan menurut Yousef (2000) memiliki tiga dimensi: kecenderungan kognitif, kecenderungan afektif, dan kecenderungan berperilaku. Masing-masing dimensi tersebut memiliki pengaruh pada cara pandang karyawan dalam menghadapi suatu perubahan. Apakah perubahan akan dipandang sebagai sesuatu yang positif atau akan dipandang sebagai sesuatu yang negatif. Jika perubahan dipandang sebagai sesuatu yang positif, maka akan mudah mencapai tujuan dari organisasi tersebut (Eby et al, 2000).

Komitmen organisasi adalah salah satu faktor yang berpengaruh terhadap kinerja (Ahmed \& Ramay, 2010). Komitmen adalah suatu sikap dedikasi terhadap organisasi dan kemauan untuk mau bekerja keras (Meyer \& Allen, 1988) Seorang karyawan yang memiliki komitmen terhadap organisasinya maka dia akan berusaha semaksimal mungkin untuk mencapai tujuan organisasi yang telah ditetapkan.

Tingkat usaha yang tinggi dari seorang karyawan dengan level tinggi dari komitmen organisasi akan mendorong pada tingkat kinerja dan keefektifan yang lebih tinggi dari karyawan terhadap organisasi (Sharma \& Bajpai, 2010). Komitmen organisasi menurut Meyer \& Allen (1988) berasal dari tiga dimensi yang berbeda, yakni affective commitment yang mana mengukur tingkat emosional karyawan, identifikasi, dan keterlibatan didalam organisasi. Normative commitment menggambarkan tekanan pada karyawan untuk tinggal dengan perusahaan atau organisasi dari tanggung jawab perusahaan. Continuance commitment merujuk pada komitmen yang berasosiasi dengan beban-beban yang dirasakan oleh karyawan yang berkaitan dengan keinginan untuk meninggalkan organisasi.

Etika atau dalam penelitian ini etika kerja Islam merupakan faktor lain yang memiliki pengaruh terhadap kinerja (Imam \& Sattar, 2013). Yousef (2000) dalam penelitiannya menemukan bahwa etika kerja Islam memberikan dampak terhadap kinerja karyawan dalam sebuah organisasi. Setiap organisasi pasti menerapkan aturan yang berisi etika untuk mengatur tingkah laku karyawannya didalam organisasi. Aturan atau etika ini bertujuan agar karyawan bisa mencapai tujuan organisasi pada batasan-batasan yang telah ditentukan.

Perkembangan zaman telah memberikan dampak besar terhadap etika. Seiring berjalannya waktu, etika mulai berkembang sesuai dengan karakteristik organisasi. Didalam organisasi yang memiliki budaya Islam, etika mulai berkembang pada sebuah aturan yang berdasarkan pada kitab suci yakni Al-Quran dan sumber pendukung lain seperti Sunnah.

Berjalannya waktu dan berkembangnya teknologi informasi ternyata memberikan dampak yang besar terhadap perubahan dunia pendidikan. Perubahan yang terjadi tersebut tidak lain adalah karena adanya pengaruh lingkungan yang menuntut organisasi pendidikan untuk berubah. Dalam hal ini pemerintah sebagai regulator 
dalam dunia pendidikan memiliki andil yang besar dalam mempengaruhi perubahan didalam organisasi pendidikan. Adanya tuntutan dari masyarakat yang memimpikan sistem pendidikan yang semakin baik merupakan faktor pendorong perubahan lainnya.

Sebagai seorang pendidik, guru diharapkan memiliki komitmen terhadap organisasi profesinya sebagaimana yang tertuang dalam Etika Profesi Keguruan yaitu professional terhadap tempat bekerja. Dengan adanya komitmen tersebut, diharapkan guru akan memiliki sikap siap dalam menghadapi perubahan ditempatnya bekerja apapun bentuknya. Sikap siap dalam menerima perubahan inilah yang akan memberikan pengaruh pada pencapaian kinerja (Susanty \& Rizqi, 2013).

Peneliti ingin melakukan penelitian pada aspek etika kerja Islam, komitmen organisasi, sikap pada perubahan terhadap kinerja dengan guru sebagai sampelnya. Hal ini didasarkan pada banyaknya tuntutan yang dihadapi profesi guru dalam menjalankan tugasnya disuatu organisasi pendidikan. Penelitian ini juga dikhususkan dilakukan pada lingkungan pendidikan yang memiliki budaya Islam, dengan maksud untuk mengetahui apakah etika kerja Islam benar-benar diaplikasikan dalam kehidupan organisasi. Sedikitnya penelitian yang dilakukan pada organsiasi non-profit khususnya didunia pendidikan yang berlatar belakang Islam juga menjadi pertimbangan bagi peneliti.

\section{KAJIAN LiterATUR DAN PENGEMBANGAN HiPOTESIS}

\section{A. Kinerja}

Mangkunegara (2009) mendefinisikan kinerja atau prestasi kerja adalah hasil kerja yang secara kualitas dan kuantitas mampu dicapai oleh karyawan dalam menjalankan kewajibannya sesuai dengan yang diberikan kepadanya. Lebih lanjut kinerja adalah sebuah fungsi motivasi atau dorongan dari kemampuan seseorang untuk menyelesaikan tanggung jawab atau tugasnya.

Rivai dan Basri (2005) mendefinisikan kinerja sebagai tingkat kesuksesan seseorang secara menyeluruh pada waktu tertentu dalam melaksanakan tugasnya dibandingkan dengan berbagai macam kemungkinan, seperti: standar kinerja, sasaran, dan kriteria. Dalam hal ini standar atau kriteria memiliki andil yang besar dalam mengukur kinerja seseorang.

\section{B. Komitmen Organisasi}

Menurut Robbins (2002) komitmen organisasi adalah sebuah sikap yang merefleksikan perasaan senang atau tidak senang terhadap organisasi. Perasaan suka terhadap organisasi ini dapat ditunjukkan melalui ketertarikan karyawan terhadap tujuan, nilai, dan sasaran organisasi serta memiliki kemauan untuk berafiliasi dengan organisasi dan bekerja keras demi tercapainya keberlangsungan organisasi.

Porter \& Boulian (1974) mengemukakan bahwa komitmen organisasi akan tercipta apabila setiap karyawan mengembangkan tiga perilaku yang saling berkaitan dengan organisasi. Perilaku tersebut adalah: (1) Identification, yaitu pemahaman terhadap tujuan organisasi, (2) Involment, yaitu sebuah perasaan terlibat pada pekerjaan dan menganggap pekerjaannya menyenangkan, (3) Loyality, yaitu perasaan bahwa organisasi adalah tempat bekerja dan tempat tinggal.

\section{Sikap Terhadap Perubahan Organisasi}

Sikap menurut Hunt (2011) adalah sebuah kecenderungan untuk menanggapi secara positif atau negatif terhadap seseorang atau sesuatu. Sedangkan sikap terhadap perubahan organisasi menurut Khatoon \& Farooq (2015)dalah sebuah sikap emosional karyawan untuk menilai dampak baik atau buruk dari suatu perubahan yang terjadi. Mereka juga mempertimbangkan perubahan sebagai bidang yang muncul dari sikap positif yang kuat (keterbukaan, kemauan untuk berubah) terhadap sikap negatif (resisten, pesimis). Berdasarkan pengertian diatas, sikap positif karyawan terhadap perubahan organisasi memiliki peran yang penting dalam tercapainya tujuan-tujuan organisasi.

Menurut Cummings \& Worley (2014) ada dua jenis perubahan, yakni perubahan yang terjadi begitu saja dan perubahan yang direncanakan. Adapun perubahan yang direncanakan merupakan perubahan yang sengaja dilakukan dan memiliki orientasi tujuan. Tujuan dari perubahan terencana ada dua, yaitu: (1) Perubahan yang dilakukan organisasi sebagai upaya perbaikan untuk menyesuaikan diri terhadap perubahan yang terjadi di lingkungannya, dan (2) Perubahan itu mengupayakan perubahan sikap pada karyawan. 


\section{Etika Kerja Islam}

Beekun (1997) mengartikan etika kerja Islam sebagai rangkaian moral yang terdiri dari prinsip-prinsip yang membedakan mana yang benar dan mana yang salah dalam konteks Islam. Ahmad \& Yusuf (2012) mengemukakan bahwa etika kerja Islam adalah seperangkat nilai-nilai atau sitem keyakinan yang bersumber dari Al-Quran dan Sunnah yang mengatur tentang pekerjaan dan kerja keras.

\section{E. Hipotesis}

Berdasarkan uraian diatas, penelitian ini dapat dirumuskan dalam tujuh hipotesis:

H1: Etika kerja Islam berpengaruh positif terhadap kinerja karyawan

H2: Etika kerja Islam berpengaruh positif terhadap sikap terhadap perubahan organisasi

H3: Etika kerja Islam berpengaruh positif terhadap kinerja karyawan dengan sikap terhadap perubahan organisasi sebagai variabel intervening

H4: Komitmen organisasi berpengaruh positif terhadap kinerja karyawan

H5: Komitmen organisasi berpengaruh positif terhadap sikap terhadap perubahan organisasi

H6: Sikap terhadap perubahan organisasi berpengaruh positif terhadap kinerja karyawan

H7: Komitmen organisasi berpengaruh positif terhadap kinerja karyawan dengan sikap terhadap perubahan organisasi sebagai variabel intervening

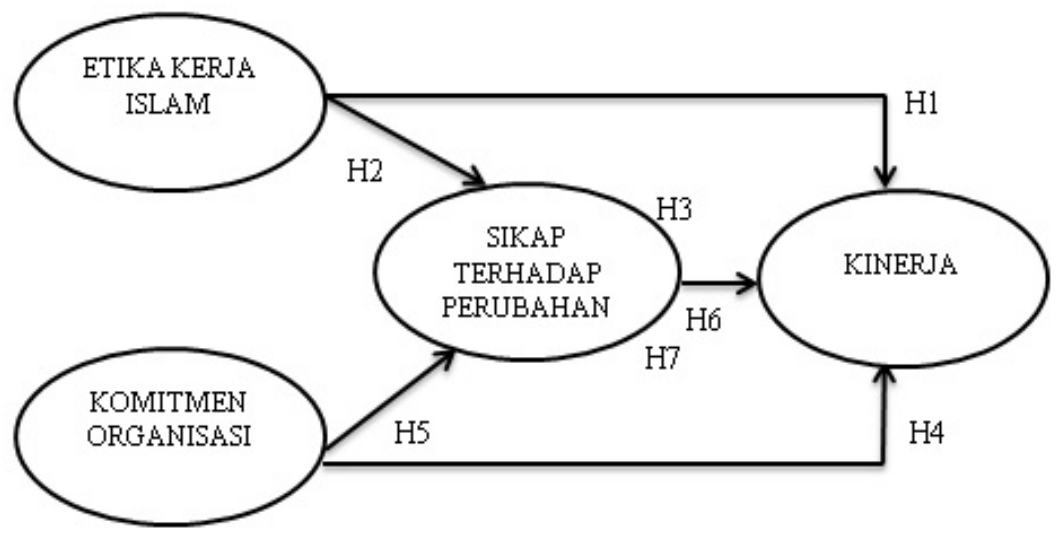

Gambar 1.Kerangka Penelitian

\section{METODE PENELITIAN}

\section{A. Jenis dan Sumber Data}

Penelitian ini termasuk dalam penelitian survei. Pengamatan dilakukan pada populasi besar maupun kecil tetapi data yang dipelajari adalah data dari sampel yang diambil dari populasi, sehingga ditemukan kejadiankejadian relatif, distribusi dan pengaruh antar variabel (Sekaran, 2006). Jenis data dalam penelitian ini yaitu: (1) Data primer, diperoleh dengan menggunakan metode angket (kuesioner) yaitu berupa daftar pertanyaan terkait kinerja, sikap pada perubahan organisasi, komitmen organisasi, dan etika kerja Islam yang diberikan kepada para responden yang telah ditunjuk sebagai sampel. (2) Data sekunder, didalam penelitian ini data sekunder yang didapat dari literatur, buku-buku yang terkait dengan topik penelitian serta data yang bersumber dari obyek penelitian yaitu jumlah guru madrasah negeri yang ada di wilayah Kabupaten Sragen dan struktur organisasi sekolah.

\section{B. Populasi, Sampel, dan Teknik Sampling}

Populasi yang diamati dalam penelitian ini adalah guru yang ada di madrasah negeri di Kabupaten Sragen yang terdiri dari Madrasah Aliyah (MA), Madrasah Tsanawiyah (MTS), dan Madrasah Ibtidaiyah (MI) yang berjumlah 676 guru. Ukuran sampel yang sesuai untuk alat analisis Structural Equation Modelling (SEM) adalah 
sebanyak 5 - 10 kali estimasi parameter (Hair et al, 1995). Berdasarkan hal tersebut, maka penelitian ini menggunakan sampel minimal sebanyak 300 responden (5 x 60 parameter) yang diharapkan sampel yang digunakan dalam penelitian bisa mewakili populasi yang ada. Pengambilan sampel dalam penelitian ini dilakukan dengan menggunakan metode Convenience Sampling. Metode tersebut merupakan sebuah cara pengambilan sampel tanpa syarat dari populasi yang dengan suka rela bersedia memberikannya (Sekaran, 2006).

\section{Metode Pengumpulan Data}

Guna mendapatkan data yang diperlukan, peneliti melakukan distribusi kuisioner berupa daftar pertanyaan kepada responden kemudian responden memilih satu jawaban dari alternatif jawaban yang sudah disediakan. Metode pengumpulan data menggunakan Personally Administrated Questionnaires, yaitu peneliti mendistribusikan sendiri kuisioner kepada responden dan mengambil kuisioner dengan tujuan agar tingkat pengembalian kuisioner terjaga dalam waktu yang relatif pendek (Sekaran, 2006).

\section{Metode Analisis Data}

Metode analisis data dalam riset ini menggunakan analisis deskriptif. Sedangkan uji instrumen penelitian menggunakan uji validitas dan reliabilitas. Serta untuk analisis data dan uji hipotesis yang akan digunakan dalam penelitian menggunakan Structural Equation Modelling (SEM) dengan menggunakan alat analisis AMOS 21.0.

\section{Analisis Deskriptif}

Analisis deskriptif digunakan untuk menganalisis data dengan cara mendeskripsikan data yang telah dikumpulkan tanpa bermaksud membuat kesimpulan yang berlaku umum (Sugiyono, 2008). Peneliti menggunakan five point likert scale untuk menganalisa kuisioner dengan skor 1 sampai dengan 5 . Hal ini dilakukan untuk memperjelas kelompok skala dan memudahkan penulis melakukan analisa item pertanyaan berdasarkan nilai rata-rata (mean) yang diperoleh.

\section{Uji Instrumen}

Uji validitas. Uji validitas yang digunakan dalam riset ini menggunakan program komputer SPSS 22 for Windows. Sebuah instrumen dikatakan valid jika: nilai KMO harus lebih besar dari 0,5; nilai Signifikansi harus lebih kecil dari 0,05; tidak terdapat item yang memiliki nilai ganda pada Rotated Component Matrix.

Uji reliabilitas. Reliabilitas adalah sebuah alat untuk mengukur suatu kuesioner yang menjadi indikator dari variabel atau konstruk. Suatu kuesioner bisa dikatakan handal atau reliabel jika jawaban seseorang ter-hadap pertanyaan yang diberikan konsisten dari waktu ke waktu (Ghozali, 2006). Uji reliabilitas dapat dilakukan dengan menggunakan Cronbach Alfa. Suatu variabel atau konstruk dikatakan reliabel jika memberikan nilai Cron-bach Alfa > 0.60 (Nunnally 1967 dalam Ghozali, 2006).

\section{Analisis Data}

Analisis data penelitian adalah bagian dari proses menguji data setelah tahap pengumpulan dan pemilihan data penelitian. Sebuah penelitian selalu memerlukan interpretasi dan analisis data yang diharapkan mampu memberikan solusi pada research question yang menjadi dasar penelitian tersebut. Metode analisis yang digunakan pada penelitian ini adalah Structural Equation Modelling (SEM) melalui program AMOS 21.0. Model persamaan Structural Equation Modelling (SEM) adalah kumpulan teknik statistik yang memungkinkan pengujian sebuah rangkaian yang memiliki hubungan "rumit" secara simultan atau menyeluruh (Ferdinand, 2006).

\section{HASIL DAN PEMBAHASAN}

\section{A. Uji Instrumen Penelitian}

Uji validitas. Uji ini dilakukan terhadap empat variabel utama dalam penelitian ini, yaitu: komitmen organisasi, etika kerja Islam, sikap terhadap perubahan organisasi, dan kinerja. Uji validitas pada penelitian ini dilakukan dengan teknik Confirmatory Factor Analysis (CFA) menggunakan program SPSS 22. Hasil KMO 
menunjukkan bahwa Measure of Sampling Adequacy sebesar 0,749 > 0,5 dengan nilai signifikansi sebesar 0,000 $<0,05$. Hal ini menunjukkan bahwa variabel dalam penelitian ini valid.

Uji reliabilitas. Pengujian ini dilakukan menggunakan Cronbach Alfa. Suatu variabel dikatakan reliabel jika memiliki nilai Cronbach Alfa > 0,60 (Nunnally \& Berstein, 1994). Semua variabel yang diteliti pada penelitian ini adalah reliabel. Karena setiap variabel mempunyai nilai Cronbach Alfa: etika kerja Islam 0,720 > 0,60; komitmen organisasi 0,684 > 0,60; sikap terhadap perubahan organisasi 0,702 > 0,60; dan kinerja 0,664 >0,60.

\section{B. Analisis Data}

Sebelum dilakukan pengujian hipotesis, terdapat beberapa asumsi SEM yang harus terpenuhi, asumsi tersebut meliputi asumsi kecukupan sampel, outliers dan normalitas. Berdasarkan hasil pengolahan uji normalitas diperoleh cr skewness lebih dari -2,58. Akan tetapi pada nilai c.r. kurtosis tidak terdapat nilai yang melebihi -2,58 maupun +2,58, serta memiliki nilai c.r. kurtosis multivariate di bawah 7, dengan begitu data pada penelitian ini termasuk normal. Berdasarkan pengukuran goodness-of-fit melalui modifikasi model terindikasi bahwa model yang diajukan pada penelitian ini bisa diterima. Hal ini dapat dilihat pada tabel dibawah ini:

Tabel 1 Hasil Pengujian Goodness of Fit Model Modifikasi

\begin{tabular}{lccc}
\hline \multicolumn{1}{c}{$\begin{array}{c}\text { Indeks } \\
\text { Model Goodness of Fit }\end{array}$} & $\begin{array}{c}\text { Cut-off } \\
\text { Value }\end{array}$ & $\begin{array}{c}\text { Hasil } \\
\text { Model }\end{array}$ & Kesimpulan \\
\hline Chi Square & Diharapkan kecil & 758,865 & Fit \\
Probabilitas Chi Square ( $\mathrm{p}$ ) & $\geq 0,05$ & 0,231 & Fit \\
CMIN/DF & $\leq 2,00-3,00$ & 1,038 & Marginal \\
Adjusted goodness of fit index & $\geq 0,90$ & 0,857 & Fit \\
(AGFI) & $\geq 0,95$ & 0,960 & Fit \\
Comparative fit index (CFI) & $\geq 0,95$ & 0,953 & Fit \\
Tucker-Lewis Index (TLI) & $\leq 0,08$ & 0,011 & \\
Root mean square error & & & \\
approximation (RMSEA) & &
\end{tabular}

C. Uji Hipotesis

Tabel 2. Hasil Pengujian Hipotesis

\begin{tabular}{|c|c|c|c|c|c|}
\hline Hubungan Variabel & Estimate & S.E. & C.R & $P$ & Kesimpulan \\
\hline Sikap <--- Etika &,- 188 & .175 & $-1,072$ & .284 & Tidak Sinifikan \\
\hline Sikap <-- Komitmen & .384 & ,086 & 4,462 & הtה & Signifikan \\
\hline Kinerja <--- Sikap & .736 &, 131 & 5,622 & \#ה & Signifikan \\
\hline Kinerja <-- Etika & .274 & .225 & 1,217 &, 224 & Tidak Sinifikan \\
\hline Kinerja <-- Komitmen & -.155 & .126 & $-1,236$ & 217 & Tidak Sinifikan \\
\hline
\end{tabular}

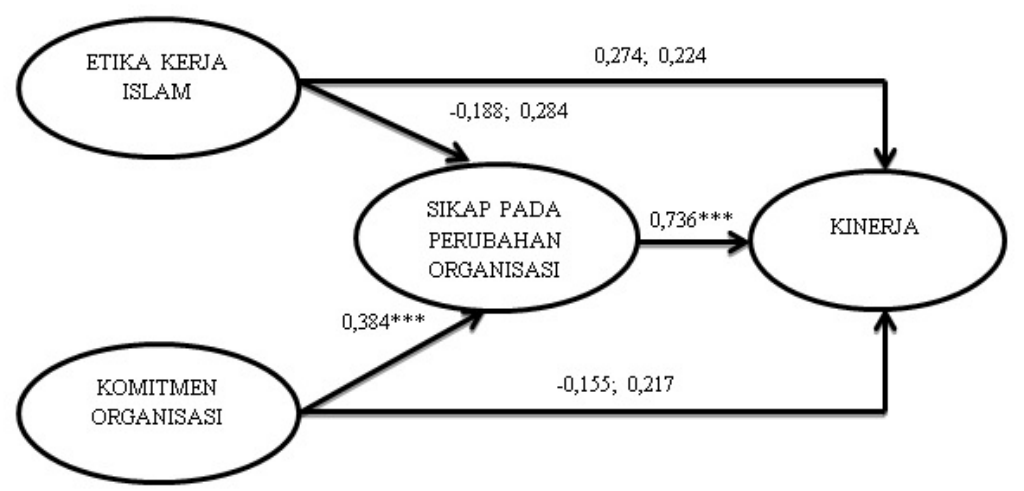

Gambar 2 Hasil Pengujian Hipotesis 
Tabel 3. Uji Mediasi dengan Sobel Test

\begin{tabular}{|c|c|c|}
\hline Test Statistic & Standart Error & P - Value \\
\hline 3,495 & 0,080 & 0,00047 \\
\hline
\end{tabular}

Analisis kausalitas dilakukan untuk mengetahui hubungan antara variabel dalam penelitian. Dalam penelitian ini diharapkan melalui pengujian kausalitas bisa diketahui pengaruh yang terjadi antara variabel eksogen terhadap variabel endogen. Hasil uji hipotesis ditampilkan pada tabel diatas.

Selain hubungan antar variabel, dalam penelitian ini juga diteliti hubungan mediasi. Hubungan mediasi pertama yaitu antara etika kerja Islam terhadap kinerja dengan variabel intervening sikap terhadap perubahan organisasi. Dalam hubungan tersebut variabel sikap terhadap perubahan organisasi tidak memberikan pengaruh mediasi antara etika kerja Islam terhadap kinerja. Hal ini dikarenakan tidak adanya pengaruh antara etika kerja Islam pada sikap terhadap perubahan organisasi dan kinerja.

Hubungan mediasi kedua yaitu komitmen organisasi terhadap kinerja dengan sikap terhadap perubahan organisasi sebagai mediasi. Melalui uji mediasi dengan Sobel Test diperoleh nilai signifikansi sebesar $0,00047 \leq$ 0,05 yang berarti signifikan, sehingga variabel sikap terhadap perubahan organisasi diterima sebagai mediasi dan termasuk mediasi penuh (full mediation).

\section{Pembahasan}

1. Etika kerja Islam memiliki pengaruh positif terhadap kinerja karyawan

Hasil pengolahan data hipotesis 1 menunjukkan nilai CR hubungan antara etika kerja Islam terhadap kinerja adalah sebesar $1,217<2$ dengan nilai $\mathrm{P}$ sebesar 0,224 > 0,05 yang berarti hipotesis 1 dalam penelitian ini ditolak. Dalam penelitian yang telah dilakukan bisa disimpulkan bahwa variabel etika kerja Islam tidak berpengaruh positif signifikan terhadap kinerja karyawan. Artinya tinggi rendahnya etika kerja Islam yang dimiliki oleh guru madrasah, tidak akan memberikan pengaruh pada kinerja mereka.

Hasil uji hipotesis 1 dalam penelitian ini bertentangan dengan penelitian yang pernah dilakukan oleh Imam \& Sattar (2013) dan Hadisi (2014). Hal ini dikarenakan sistem penilaian kinerja dan standar kerja guru yang sama di lingkungan madrasah. Etika kerja Islam merupakan sikap, kebiasaan atau cara berfikir seseorang terhadap pekerjaan sesuai dengan aturan Islam. Ketika seorang guru memiliki etika kerja Islam yang tinggi ataupun rendah mereka tetap akan memiliki target kerja yang sama, tanpa memperhatikan aspek kualitas pekerjaannya.

\section{Etika kerja Islam memiliki pengaruh positif terhadap sikap pada perubahan organisasi}

Hasil pengolahan data untuk hipotesis 2 menunjukkan nilai CR hubungan antara etika kerja Islam terhadap sikap pada perubahan organisasi adalah sebesar $-1,072<2$ dengan nilai $\mathrm{P}$ sebesar 0,284 $>0,05$ yang artinya hipotesis 2 yang diajukan dalam penelitian ini ditolak. Dalam penelitian yang telah dilakukan bisa disimpulkan bahwa variabel etika kerja Islam tidak berpengaruh positif terhadap sikap pada perubahan organisasi. Artinya tinggi atau rendahnya etika kerja Islam yang dimiliki oleh guru tidak akan berdampak pada sikap guru terhadap perubahan organisasi.

Hasil uji hipotesis dalam penelitian ini berbeda dengan penelitian yang pernah dilakukan oleh Ahmed \& Ramay (2010) dan Yousef (2000). Namun hasil dalam penelitian ini sejalan dengan penelitian yang pernah dilakukan oleh Januarti \& Bunyaanudin (2006). Alasan tidak berpengaruhnya etika kerja Islam terhadap sikap pada perubahan organisasi di sekolah madrasah adalah karena lingkungan budaya organisasi yang sudah memiliki karakteristik yang permanen.

Budaya organisasi yang sudah terbentuk lama didalam organisasi akan kuat bertahan dan mengakar terhadap perubahan yang terjadi. Intinya penolakan ini dikarenakan anggota organisasi menghendaki suatu kondisi yang stabil dimana pada kondisi tersebut akan berdampak pada tingkat stabilitas dan perilaku yang dapat diprediksikan meskipun dengan penolakan tersebut akan bisa menghambat adaptasi dan kemajuan serta perkembangan organisasi (Robbins, 2002). 
3. Etika kerja Islam berpengaruh positif terhadap kinerja karyawan dengan sikap terhadap perubahan organisasi sebagai variabel intervening

Hasil penelitian pada hipotesis 3 menunjukkan bahwa sikap terhadap perubahan organisasi tidak memediasi hubungan antara etika kerja Islam pada kinerja. Hal ini dikarenakan tidak adanya pengaruh antara etika kerja Islam pada sikap terhadap perubahan organisasi dan terhadap kinerja. Karena itu hipotesis 3 pada penelitian ini ditolak.

Melalui hasil uji hipotesis 3 bisa diketahui bahwa sikap terhadap perubahan organisasi tidak mampu memberikan pengaruh mediasi hubungan antara etika kerja Islam pada kinerja. Artinya ketika guru memiliki etika kerja Islam yang tinggi maupun rendah tidak akan mempengaruhi kinerja guru meskipun guru memiliki sikap terhadap perubahan organisasi.

Hal ini dikarenakan guru menganggap perubahan yang terjadi didalam organisasi merupakan sesuatu yang harus diterima dan dilaksanakan. Karena posisi guru adalah pelaksana kebijakan yang bersumber dari pemerintah pusat, sehingga mereka tidak memiliki pilihan untuk menolak perubahan didalam organisasi apapun itu konsekuensinya.

\section{Komitmen organisasi memiliki pengaruh positif terhadap kinerja karyawan}

Hasil pengolahan data pada hipotesis 4 menunjukkan nilai CR komitmen organisasi pada kinerja adalah sebesar $-1,236<2$ dengan nilai P sebesar 0,217 > 0,05. Artinya hipotesis 4 dalam penelitian ini ditolak. Dalam penelitian yang telah dilakukan dapat diambil kesimpulan bahwa variabel komitmen organisasi tidak berpengaruh positif pada kinerja karyawan.

Hasil uji hipotesis 4 pada penelitian ini berbeda dengan penelitian yang dilakukan oleh Ahmed \& Ramay (2010) dan Susanty \& Rizqi (2013). Namun hasil penelitian ini sejalan dengan penelitian yang dilakukan Supriyanto (2014) yang menemukan hubungan bahwa komitmen organisasi tidak berpengaruh positif signifikan terhadap kinerja. Perbedaan yang ada bisa disebabkan karakteristik sampel atau organisasi penelitian dimana memungkinkan adanya perbedaan antara organisasi yang bersifat profit oriented dan non profit oriented.

Tinggi atau rendahnya komitmen organisasi yang dimiliki oleh guru tidak akan memberikan pengaruh atau berpengaruh tetapi tidak signifikan terhadap kinerja guru. Hal ini terjadi karena lingkungan madrasah yang cenderung stabil. Stabil disini lebih mengarah pada sistem reward yang berlaku dilingkungan madrasah terhadap kinerja. Sebagai contoh seperti besaran jumlah gaji dan kenaikan pangkat yang berjalan sesuai dengan sistem yang berlaku tanpa adanya pengaruh dari komitmen organisasi yang dimiliki guru.

\section{Komitmen organisasi memiliki pengaruh positif pada sikap terhadap perubahan organisasi}

Hasil pengolahan data untuk hipotesis 5 menunjukkan nilai CR komitmen organisasi pada sikap terhadap perubahan organisasi adalah sebesar 4,462 dengan nilai P sebesar 0,000. Hasil yang diperoleh menunjukkan bahwa nilai CR lebih dari 2,0 dan nilai P kurang dari 0,05, artinya hipotesis 5 dalam penelitian ini bisa diterima. Dalam penelitian yang telah dilakukan bisa diambil kesimpulan bahwa variabel komitmen organisasi memiliki pengaruh positif signifikan terhadap sikap pada perubahan organisasi.

Hasil dalam penelitian ini sesuai dengan penelitian yang pernah dilakukan oleh Yousef (2000), Vakola \& Nikolaou (2005), dan Januarti \& Bunyaanudin (2006). Anggota organisasi yang memiliki sikap komitmen terhadap organisasi akan memiliki sikap kerelaan untuk menerima segala bentuk perubahan di dalam organisasi. Selain itu, alasan lain yang mendukung diterimanya hipotesis ini adalah mayoritas guru madrasah yang berstatus sebagai Pegawai Negeri Sipil (PNS) yang cenderung patuh terhadap perubahan-perubahan organisasi yang bersumber dari aturan pusat.

\section{Sikap terhadap perubahan organisasi berpengaruh positif terhadap kinerja}

Hasil pengolahan data pada hipotesis 6 menunjukkan nilai CR hubungan antara sikap terhadap perubahan organisasi pada kinerja adalah sebesar 5,622 $>2$ dengan nilai P sebesar 0,000 $<0,05$, yang artinya hipotesis 6 dalam penelitian ini diterima. Dalam penelitian yang telah dilakukan dapat disimpulkan bahwa variabel sikap terhadap perubahan organisasi berpengaruh positif terhadap kinerja.

Didalam sekolah madrasah, perubahan-perubahan yang terjadi didalam organisasi sebagian besar bersumber dari aturan-aturan pusat yang dibuat oleh Kementrian Agama. Aturan tersebut dibuat guna me-nunjang dan menjaga kualitas pendidikan madrasah serta profesionalitas guru. Guru madrasah memiliki posisi sebagai 
pelaksana kebijakan. Sikap siap menerima segala bentuk perubahan tersebut diharapkan mampu mendongkrak kinerja guru. Karena pada dasarnya perubahan-perubahan yang terjadi didalam lingkungan madrasah bertujuan untuk meningkatkan kualitas pendidikan dan profesionalitas guru.

7. Komitmen organisasi berpengaruh positif terhadap kinerja dengan sikap terhadap perubahan organisasi sebagai variabel intervening

Hasil penelitian pada hipotesis 7 menunjukkan bahwa sikap terhadap perubahan organisasi memediasi hubungan antara komitmen organisasi pada kinerja karyawan, sehingga dapat disimpulkan bahwa hipotesis 7 dalam peneltian ini diterima. Hal ini dikarenakan setelah dilakukan uji mediasi dengan menggunakan Sobel Test ditemukan hasil yang signifikan. Mediasi dalam hubungan ini adalah mediasi penuh (full mediation), karena variabel komitmen organisasi tidak mampu mempengaruhi kinerja secara signifikan tanpa melalui variabel sikap terhadap perubahan organisasi.

\section{KESIMPULAN}

Berdasarkan hasil analisis dan pembahasan diatas, maka bisa didapatkan kesimpulan sebagai berikut:

1. Hipotesis 1 dalam penelitian ini ditolak, yaitu etika kerja Islam tidak memiliki pengaruh pengaruh positif signifikan terhadap kinerja. Artinya tinggi atau rendahnya etika kerja Islam yang dimiliki oleh guru tidak akan memberikan pengaruh pada kinerja guru.

2. Hipotesis 2 dalam penelitian ini ditolak, yaitu etika kerja Islam tidak memiliki pengaruh positif signifikan pada sikap terhadap perubahan organisasi. Artinya tinggi atau rendahnya etika kerja Islam yang dimiliki oleh guru tidak akan memberikan pengaruh pada sikap guru terhadap perubahan organisasi.

3. Hipotesis 3 dalam penelitian ini ditolak, yaitu sikap terhadap perubahan organisasi tidak memediasi hubungan antara etika kerja Islam pada kinerja. Artinya guru yang memiliki etika kerja Islam baik tinggi maupun rendah, kinerjanya tidak akan berpengaruh ketika guru memiliki sikap terhadap perubahan organisasi.

4. Hipotesis 4 dalam penelitian ini ditolak, yaitu komitmen organisasi tidak memiliki pengaruh positif terhadap kinerja. Artinya tinggi rendahnya komitmen organisasi yang dimiliki guru tidak akan berdampak pada kinerja mereka.

5. Hipotesis 5 dalam penelitian ini diterima, yaitu komitmen organisasi memiliki pengaruh positif signifikan pada sikap terhadap perubahan organisasi. Artinya semakin tinggi komitmen organisasi yang dimiliki guru akan meningkatkan sikap guru terhadap perubahan organisasi.

6. Hipotesis 6 dalam penelitian ini diterima, yaitu sikap terhadap perubahan organisasi berpengaruh positif signifikan terhadap kinerja. Artinya semakin tinggi sikap guru terhadap perubahan organisasi maka akan meningkatkan kinerja guru.

Hipotesis 7 dalam penelitian ini diterima, yaitu sikap terhadap perubahan organisasi memediasi hubungan antara komitmen organisasi terhadap kinerja. Artinya guru yang memiliki komitmen organisasi meningkat kinerjanya jika guru juga memiliki sikap terhadap perubahan organisasi.

\section{DAFTAR PUSTAKA}

Abdul Rashid, Z., Sambasivan, M., \& Abdul Rahman, A. (2004). The influence of organizational culture on attitudes toward organizational change. Leadership \& organization development Journal, 25(2), 161-179.

Ahmad, S., \& Owoyemi, M. Y. (2012). The concept of Islamic work ethic: An analysis of some salient points in the prophetic tradition. International Journal of Business and Social Science, 3(20), 116-123.

Ahmed, F., \& Ramay, M. I. (2010). The Impact of Organizational Commitment on Employee's Job Performance. European Journal of Social Sciences, Vol. 15.

Beekun, R. I. (1997). Islamic business ethics (No. 2). International Institute of Islamic Thought (IIIT).

Cummings, T. G., \& Worley, C. G. (2014). Organization development and change. Cengage learning.

Eby, L. T., Adams, D. M., Russell, J. E., \& Gaby, S. H. (2000). Perceptions of organizational readiness for change: Factors related to employees' reactions to the implementation of team-based selling. Human relations, 53(3), 419-442.

Ferdinand, A. (2002). Structural equation modeling dalam penelitian manajemen. Semarang: Badan Penerbit Universitas Diponegoro. 
Ghozali, I. (2006). Aplikasi analisis multivariate dengan program SPSS. Badan Penerbit Universitas Diponegoro.

Hadisi, M. (2014). The effect of Islamic work ethics on the performance result of Muslim employees of marketing sector in the multinational companies. International Journal of Organizational Leadership, 3(1), 31.

Hair, J. F., Anderson, R. E., Tatham, R. L., \& Black, W. C. (1995). Multivariate Data Analysis (4 ${ }^{\text {th }}$ Edition). New Jersey: Prentice Hall Inc.

Hunt, J. G. (2011). Organizational Behavior, $11^{\text {th }}$ Edition. Pensylvania: John Wiley \& Sons, Inc.

Imam, A., Abbasi, A. S., \& Muneer, S. (2013). The impact of Islamic work ethics on employee performance: testing two models of personality X and personality Y. Science International (Lahore), 25(3), 611-617.

Januarti, I., \& Bunyaanudin, A. (2006). Pengaruh Komitmen Organisasional dan Keterlibatan Kerja Terhadap Hubungan Antara Etika Kerja Islam dengan Sikap Terhadap Perubahan Organisasi. Jurnal Akuntansi dan Auditing Indonesia, 10(1).

Khatoon, S., \& Farooq, A. (2015). Employees' Attitude toward Change and Organizational Performance. Research and Sustainable Business, 347.

Mangkunegara, A. P. (2009). Manajemen Sumber Daya Perusahaan. Bandung: PT. Remaja Rosdaharja.

Meyer, J. P., \& Allen, N. J. (1988). Links Between Work Experience and Organizational Commitment During the First Year of Employment: A Longitudinal Analysis. Journal of Occupational Psychology. Vol. 61 (3): 195-209.

Nunnaly, J., \& Bernstein, I. H. (1994). Psychometric Theory. New York: McGraw-Hill.

Porter, L. W., Steers, R. M., Mowday, R. T., \& Boulian, P. V. (1974). Organizational commitment, job satisfaction, and turnover among psychiatric technicians. Journal of applied psychology, 59(5), 603.

Prasetya, A., \& Kato, M. (2011, July). The effect of financial and non-financial compensation to the employee performance. In The 2nd International Research Symposium in Service Management. Yogyakarta, Indonesia.

Rivai, V., \& Basri, A. F. M. (2005). Performance appraisal: Sistem yang tepat untuk menilai kinerja karyawan dan meningkatkan daya saing perusahaan. PT RajaGrafindo Persada.

Robbins, S. P., \& Organisasi, P. P. P. (2002). Prinsip-Prinsip Perilaku Organisasi Edisi 5. Jakarta: Erlangga.

Sekaran, U. (2006). Research Methods for Business: A Skill Building Aproach $4^{\text {th }}$ Edition. New Jersey: John Wiley \& Sons., Inc.

Sharma, J. P., \& Bajpai, N. (2010). Organizational commitment and its impact on job satisfaction of employees: A comparative study in public and private sector in India. International Bulletin of Business Administration, 9(1), 7-19.

Sugiyono. (2008). Metode Penelitian Bisnis. Bandung: Alfabeta.

Supriyanto, A. (2014). Pengaruh Kepuasan Kerja, Kepemimpinan Transformasional, dan Komitmen Organisasi pada Kinerja Karyawan, dengan Organizational Citizanship Behavior (OCB) sebagai Variabel Mediasi. Tesis yang Dipublikasikan. Surakarta: Program Studi Magister Manajemen Universitas Sebelas Maret.

Susanty, A., Miradipta, R., \& Jie, F. (2013). Analysis of the effect of attitude toward works, organizational commitment, and job satisfaction, on employee's job performance. European Journal of Business and Social Sciences, 1(10), 15-24.

Vakola, M., \& Nikolaou, I. (2005). Attitudes towards organizational change: What is the role of employees' stress and commitment?. Employee relations, 27(2), 160-174.

Yousef, D. A. (2000). Organizational commitment as a mediator of the relationship between Islamic work ethic and attitudes toward organizational change. Human Relations, 53(4), 513-537. 


\begin{tabular}{|c|c|c|}
\hline & This Journal is available in Telkom University online Journals & $\because:: 8::: 8:$ \\
\hline & Jurnal Manajemen Indonesia & $: \because:::::_{0}^{\prime}$ \\
\hline Telkom & Journal homepage: journals.telkomuniversity.ac.id/ijm & $\begin{array}{l}\text { JURNAL } \\
\text { MANAJEMEN } \\
\text { INDONESIA }\end{array}$ \\
\hline
\end{tabular}

\title{
Customer Perception on Prulink Product Purchase Decision: A Case of Greater Jakarta Area
}

\author{
Rendika Nugraha ${ }^{1}$, Farida Komalasari ${ }^{2}$, Sandra Dethionia ${ }^{3}$ \\ ${ }^{1}$ President University, Bekasi, Indonesia \\ ${ }^{2}$ President University, Bekasi, Indonesia \\ ${ }^{3}$ President University, Bekasi, Indonesia
}

\begin{abstract}
Purpose of this research is to find out the influence of customer perception of unit link insurance product (Prulink) purchase decision through four aspects which are; information, premium, investment and risk. This research used quantitative analysis approach utilizing questionnaire, which consist of 20 items of questions as the instrument. Questionnaires were spread to customer of PT. Prudential Life Assurance Jakarta that located in Jakarta greater area as population sampling of this research. Data analysis was conducted by checking the validity (KMO and Bartlett't Test) and reliability (Cronbach Alpha) of the data. Inferential analysis was conducted using multiple regression analysis to check relationship between dependent variable and independent variable. Pre-test has been conducted to 30 people with results that questionnaire reliable to be distributed after obtain .974 on Cronbach's Alpha, validity in range .751 to .933 and reliability in range of .858 to .936 of 200 samples data that shows that each dependent and independent variables passed to hypothesis testing with multiple regression analysis. Towards this research, it is found that three aspects of customer perception, which are information, premium, and investment, have significant influence on purchase decision. On the other hand, there is no significant partial influence from risk aspect. Combining the common variable (Information, premium, and risk) with specific variable (investment) believed to become uniqueness of this research considering there might be other studies which have similar variable but without combining common variable with specific variable.
\end{abstract}

Keywords - Customer Perception; Information; Premium; Investment; Purchase decision; Insurance.

\begin{abstract}
Abstrak
Tujuan dari penelitian ini untuk mengetahui pengaruh dari persepsi pelanggan dari produk asuransi unit link (Prulink) melalui empat aspek keputusan pembelian yaitu informasi, premi, investasi dan resiko. Penelitian ini menggunakan metode kuantitatif dengan kuosioner yang terdiri dari dua puluh pertanyaan sebagai instrument. Kuosioner disebarkan kepada pelangan dari PT. Priudential life Assurance Jakarta yang terletak di area Jakarta sebagai sample populasi dari penelitian ini. Analisa data dilakukan dengan menggunakan tes validitas (KMO and Bartlett't Test) dan reliabilitas (Cronbach Alpha). Analisa inferensial dilakukan dengan analisis regresi berganda untuk mengetahui hubungan antara variabel tak bebas dan variabel bebas. Ujicoba telah dilakukan kepada tiga puluh orang dengan hasil bahwa kuosioner layak untuk disebarkan setelah mendapatkan nilai .974 pada Cronbach's alpha, validitas dalam cakupan .751 sampai .933 dan reliabilitas dalam cakupan .858 sampai .936 sampai dari 200 data sampel yang menunjukkan bahwa variabel tak bebas dan variabel bebas telah lulu uji hipotesis dengan analisis regresi berganda. Melalui penelitian ini, ditemukan tiga aspek dari persepsi pelanggan yaitu informasi, premi dan investasi yang mempunyai pengaruh yang signifikan terhadap keputusan pembelian. Di sisi lain, tidak ada pengaruh parsial yang signifikan dari aspek resiko. Mengombinasikan variabel umum (informasi, premi, dan resiko dengan variabel khusus (investasi) dipercaya menjadi keunikan dari riset ini mengingat ada kemungkinan dari penelitian/studi lain yang mempunyai variabel yang sama tetapi tanpa mengombinasikan variabel umum dengan variabel khusus.
\end{abstract}

Kata kunci- Persepsi Pelanggan; Informasi; Premi; Investasi; Keputusan Pembelian; Asuransi.

\section{Article info}

Received ( $1^{\text {st }}$ August, 2018)

Revised (16 ${ }^{\text {th }}$ August, 2018)

Accepted (25 $5^{\text {th }}$ August, 2018)

Corresponding_author: rendika@president.ac.id 